\title{
Classifying Urban Meteorological Stations Sites by "Local Climate Zones": Preliminary Results for the City of Novi Sad (Serbia)
}

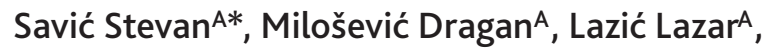 \\ Marković Vladimir ${ }^{B}$, Arsenović Daniela ${ }^{B}$, Pavić Dragoslav ${ }^{A}$ \\ Received: September 2013 | Revised: September 2013 | Accepted: September 2013
}

\begin{abstract}
Conventional approach in the investigation of urban climate of Novi Sad has been done through simple urban-rural air temperature differences. These inter-urban air temperature differences showed how much is city warmer than its surroundings, so-called urban heat island (UHI) effect.

Temperature differences exist inside the city as well. To get to know the intensity of these intra-urban temperature differences, installation of meteorological stations in different parts of the city or mobile measurements are needed.

In 2012 started IPA HUSRB project made by Department of Climatology and Landscape Ecology (University of Szeged) and Faculty of Sciences (University of Novi Sad). The main goal of this project is the development and installation of wireless urban meteorological network (temperature and relative humidity sensors) in Szeged and Novi Sad.

Before the deployment of sensors, necessary metadata about each potential urban meteorological station site needs to be collected. Field work, collected metadata and Stewart and Oke climate-based classification system from 2012 were used for defining the potential urban meteorological stations sites on the territory of the city of Novi Sad (Serbia) and its surroundings.
\end{abstract}

Key words: local climate zone, urban heat island, urban metorological network, site clasiffication, Novi Sad, Serbia

\section{Introduction}

Urbanization in Serbia has reached significant level with $59 \%$ of population living in cities in 2011 (UN, 2012). As urban areas develop, artificial objects replace open land and vegetation and influence microclimate conditions in the city. Among the parameters of the urban atmosphere the near-surface (1.5-2 $\mathrm{m}$ above ground level or screen-height) air temperature shows the most obvious modification compared to the ru- ral area (Oke, 1987). This is a phenomenon where urban regions experience higher temperature values $\left(T_{u}\right)$ than their rural surroundings $\left(\mathrm{T}_{\mathrm{r}}\right)$. This urban warming is commonly referred to as the urban heat island ${ }^{1}$ (UHI) and its magnitude is the UHI intensity $\left(\Delta \mathrm{T}_{\mathrm{u}-\mathrm{r}}\right)$.

\footnotetext{
1 "Urban heat island," a term first coined in the 1940s (Balchin and Pye, 1947), refers to the atmospheric warmth of a city compared to its countryside.
}

A Climatology and Hydrology Research Centre, Faculty of Science, University of Novi Sad; Trg Dositeja Obradovića 3, 21000 Novi Sad, Serbia

B Center for Spatial Information of Vojvodina Province, Faculty of Science, University of Novi Sad; Trg Dositeja Obradovića 3, 21000 Novi Sad, Serbia

* Corresponding author: Stevan Savić, e-mail: stevan.savic@dgt.uns.ac.rs 
Conventional approach in the investigation of UHI in Novi Sad has been done through simple urban-rural air temperature differences. Results from previous studies showed that UHI phenomenon exists in Novi Sad (Lazić et al., 2006; Popov and Savić, 2010; Unger et al., 2011a; Unger et al. 2011b; Savić et al., 2012) which contributed to the further research of this phenomenon in the city.

Temperature differences does not exist only between city and its surroundings, but they are also present inside the city as well. For the investigation of these intra-urban temperature differences, installation of meteorological stations in different parts of the city or mobile measurements are needed.

In 2012 started IPA HUSRB project made by Department of Climatology and Landscape Ecology (University of Szeged) and Faculty of Sciences (University of Novi Sad). The main goal of this project is the development and installation of wireless urban meteorological network in Szeged and Novi Sad. In Novi Sad area, the idea is to install 27 meteorological stations which will provide air temperature and relative humidity data on the city territory and its surroundings.

Before the deployment of sensors, necessary metadata about each potential urban meteorological station site needs to be collected. Using the collected information, each station was classified according to the new climate-based classification system developed by Stewart and Oke (2012) which is used for classification of urban and rural sites for the purpose of UHI studies.

\section{Study area}

Novi Sad is located in the northern part of the Republic of Serbia (figure 1) and in southeastern part of Pannonian Plain $\left(45^{\circ} 15^{\prime} \mathrm{N}, 19^{\circ} 50^{\prime} \mathrm{E}\right)$. The area of the city is characterized by plain relief with elevation from 80 to $86 \mathrm{~m}$ and its climate is free from orographic effects. The Danube River flows by the southern and southeastern edge of the city urban area. Southern parts of the city urban area (Sremska Kamenica and Petrovaradin) are located on the northern slopes of Fruška Gora Mountain (539 m). In Novi Sad the annual mean air temperature is $11.1^{\circ} \mathrm{C}$ with an annual range of $22.1^{\circ} \mathrm{C}$ and the precipitation amount is $615 \mathrm{~mm}$ (based on data from 1949 to 2008).

According to Koppen-Geiger climate classification, the region around Novi Sad is categorized as Cfa climate (temperate warm climate with a rather uniform annual distribution of precipitation) (Lazić and Pavić, 2003; Kottek et al., 2006).

Novi Sad is the second largest city in the country with a population of about 320 ooo in a built-up area

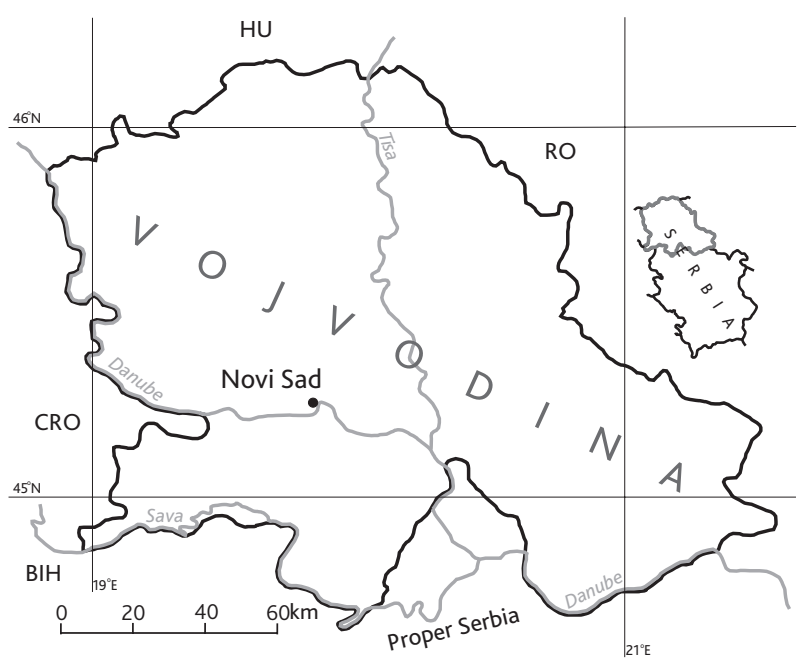

Figure 1. Geographical location of Novi Sad in Vojvodina (Northern Serbia)

of around $80 \mathrm{~km}^{2}$. It is characterized by densely built central area and its surroundings with high buildings and little free space between them. In the northern part of the city is an industrial zone. Green areas in the urban area are found near the Danube, in parks and in suburbs (Unger et al., 2011a).

\section{Data and methodology}

Up to now, several urban and rural landscape classifications were developed (Chandler, 1965; Auer, 1978; Ellefsen, 1991; Oke, 2004, 2008; Loridan and Grimmond, 2011, etc.) which contain many features that align with the aims of UHI investigation. Stewart and Oke (2012) developed a climate-based classification system based on the above mentioned earlier studies from the last decades, as well as a thorough review on the empirical heat island literature and world-wide surveys of the measurement sites with their surroundings (Unger et al, 2013).

In this paper, new climate-based classification system developed by Srewart and Oke (2012) was used for describing the local physical conditions around the temperature and relative humidity measuring field sites on the territory of Novi Sad and its surroundings. The elements of this system are the "local climate zones" (LCZs) and they are presented shortly in table 1.

The LCZ types can be distinguished by their measurable physical properties (parameters). These parameters are partly dimensionless (e.g. sky view factor), partly given in \% (e.g. building surface fraction), $m$ (height of roughness elements), etc. and their values have different ranges according to the different types (table 2). LCZs are defined as "regions of uniform surface cover, structure, material, and human activity that span hundreds of meters to several kilome- 
Table 1. Names and designation of the LCZ types (after Stewart and Oke, 2012)

\begin{tabular}{|c|c|c|}
\hline Built types & Land cover types & $\begin{array}{l}\text { Variable land } \\
\text { cover properties }\end{array}$ \\
\hline $\begin{array}{l}\text { LCZ } 1 \text { - Compact } \\
\text { high-rise } \\
\text { LCZ } 2 \text { - Compact } \\
\text { mid-rise } \\
\text { LCZ } 3 \text { - Compact } \\
\text { low-rise } \\
\text { LCZ } 4 \text { - Open } \\
\text { high-rise } \\
\text { LCZ } 5 \text { - Open } \\
\text { mid-rise } \\
\text { LCZ } 6 \text { - Open } \\
\text { low-rise } \\
\text { LCZ } 7 \text { - } \\
\text { Lightweight } \\
\text { low-rise } \\
\text { LCZ } 8 \text { - Large } \\
\text { low-rise } \\
\text { LCZ } 9 \text { - Sparsely } \\
\text { built } \\
\text { LCZ } 10 \text { - Heavy } \\
\text { industry }\end{array}$ & $\begin{array}{l}\text { LCZ A - Dense } \\
\text { trees } \\
\text { LCZ B - Scattered } \\
\text { trees } \\
\text { LCZ C - Bush, } \\
\text { scrub } \\
\text { LCZ D - Low } \\
\text { plants } \\
\text { LCZ E - Bare rock } \\
\text { / paved } \\
\text { LCZ F - Bare soil } \\
\text { / sand } \\
\text { LCZ G - Water }\end{array}$ & $\begin{array}{l}\mathrm{b} \text { - bare trees } \\
\mathrm{s}-\text { snow cover } \\
\mathrm{d} \text {-dry ground } \\
\mathrm{w} \text { - wet ground }\end{array}$ \\
\hline
\end{tabular}

tres in horizontal scale. Each LCZ has a characteristic screen-height temperature regime that is most apparent over dry surfaces, on calm, clear nights, and in areas of simple relief." (Stewart and Oke, 2012). Among them there are ten built types (from $\mathrm{LCZ}_{1}$ to $\mathrm{LCZ}_{10}$ ) and seven land cover types (from LCZ A to LCZ G), and additionally, these types can have variable seasonal or shorter period land cover properties (Unger et al., 2013).

In the frame of this new classification system the intra-urban UHI intensity is an LCZ temperature difference $\left(\Delta \mathrm{T}_{\mathrm{LCZ}: \mathrm{X}-\mathrm{Y}}\right)$, not an "urban-rural" difference $\left(\Delta \mathrm{T}_{\mathrm{u}-\mathrm{r}}\right)$ (Stewart and Oke, 2012).

The locations of the sites of an urban station network within the city and thus the question about its appropriate configuration raises an essential problem.

Table 2. Zone properties of LCZ system (after Stewart and Oke, 2012)

\begin{tabular}{|c|c|c|}
\hline & \multicolumn{2}{|l|}{ Type of properties } \\
\hline & $\begin{array}{l}\text { Geometric, surface } \\
\text { cover }\end{array}$ & $\begin{array}{l}\text { Thermal, radiative, } \\
\text { metabolic }\end{array}$ \\
\hline 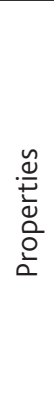 & $\begin{array}{l}\text { - } \text { sky view factor } \\
\text { - } \text { aspect ratio } \\
\text { - building surface } \\
\text { fraction (\%) } \\
\text { - impervious surface } \\
\text { fraction (\%) } \\
\text { - pervious surface } \\
\text { fraction (\%) } \\
\text { - height of roughness } \\
\text { elements (m) } \\
\text { - terrain roughness class }\end{array}$ & $\begin{array}{l}\text { - } \text { surface admittance } \\
\left(\mathrm{Jm}^{-2} \mathrm{~s}^{1 / 2} \mathrm{~K}^{-1}\right) \\
\text { - } \text { surface albedo } \\
\text { - } \text { anthropogenic heat } \\
\text { output }\left(\mathrm{Wm}^{-2}\right)\end{array}$ \\
\hline
\end{tabular}

This problem is related to the relationship between the intra-urban built and land cover LCZ types and the locations of the network sites. In the case of a planned station network (e.g. Unger et al. 2011a) in the city of Novi Sad the most important questions are: what built and land cover LCZ types can be distinguished in a given urban area, how precisely they can be delimited, how many they are and whether their extension is large enough to install a station somewhere in the middle of the area (representing the thermal conditions of this LCZ) while of course taking care to minimize the microclimatic effects of the immediate environment (Unger et al., 2013).

Field work was performed in order to define the locations of the sites of an urban station network in Novi Sad. During the visits to the potential sites of meteorological station sensors, necessary sites metadata were collected. This included the survey and assess of the local horizon, building geometry, land cover, surface wetness, surface relief, traffic flow, population density and photographs of the sites were taken. Also, secondary sources of site metadata like aerial photographs, topographic maps, satellite images (e. g. Google Earth) and published tables of property values (e. g. Stewart and Oke (2012) values of geometric, surface cover, thermal, radiative and metabolic properties; Davenport et al. (2000) terrain roughness lengths) (table 3) were used.

The urban meteorological stations will have temperature and relative humidity sensors inside them and they will be posted on the lamp posts at $4 \mathrm{~m}$ height (figure 2). They will have autonomous energy supply (battery) and will be able to recharge from the lamp post's electricity when the lamp posts are working (during night). Meteorological stations will wirelessly upload the data to a database for later processing and analysis.

\section{Results}

Collected metadata from field works and secondary sources (e.g. aerial photographs, topographic maps, published tables of property values, etc.) were used for the definition of LCZ types and station sites location within them. Each LCZ has to have minimum diameter of 400-1000 $\mathrm{m}$ so it does not overlap with surrounding LCZs of different structure or cover. It was tried to define the station location somewhere in the middle of the defined LCZs for more accurate determination of temperature and relative humidity signal.

Using above mentioned data and methods, nine LCZ types were defined on the territory of Novi Sad and its surroundings (table 4). Defined LCZ types are as follows: LCZ 2, LCZ 3, LCZ 5, LCZ 6, LCZ 8, LCZ 9, LCZ 10, LCZ B and LCZ D. First seven mentioned 
Table 3. Simplified table of selected property values for local climate zones (Stewart and Oke, 2012).

\begin{tabular}{|l|c|c|c|c|c|c|c|}
\hline Local climate zone (LCZ) & $\begin{array}{c}\text { Sky view } \\
\text { factor }^{2}\end{array}$ & $\begin{array}{c}\text { Building } \\
\text { surface } \\
\text { fraction }^{\text {b }}\end{array}$ & $\begin{array}{c}\text { Pervious } \\
\text { surface } \\
\text { fraction }^{\text {c }}\end{array}$ & $\begin{array}{c}\text { Impervious } \\
\text { surface } \\
\text { fraction }^{\text {d }}\end{array}$ & $\begin{array}{c}\text { Height of } \\
\text { roughness } \\
\text { elements }\end{array}$ & $\begin{array}{c}\text { Terrain } \\
\text { roughness } \\
\text { class }^{f}\end{array}$ & $\begin{array}{c}\text { Surface } \\
\text { albedog }^{8}\end{array}$ \\
\hline LCZ 1 Compact high-rise & $0.2-0.4$ & $40-60$ & $<10$ & $40-60$ & $>25$ & 8 & $0.10-0.20$ \\
\hline LCZ 2 Compact mid-rise & $0.3-0.6$ & $40-70$ & $<20$ & $30-50$ & $8-20$ & $6-7$ & $0.10-0.20$ \\
\hline LCZ 3 Compact low-rise & $0.2-0.6$ & $40-70$ & $<30$ & $20-40$ & $3-8$ & 6 & $0.10-0.20$ \\
\hline LCZ 4 Open high-rise & $0.5-0.7$ & $20-40$ & $30-40$ & $30-40$ & $>25$ & $7-8$ & $0.12-0.25$ \\
\hline LCZ 5 Open mid-rise & $0.5-0.8$ & $20-40$ & $20-40$ & $30-50$ & $8-20$ & $5-6$ & $0.12-0.25$ \\
\hline LCZ 6 Open low-rise & $0.6-0.9$ & $20-40$ & $30-60$ & $20-40$ & $3-8$ & $5-6$ & $0.12-0.25$ \\
\hline LCZ 7 Lightweight low-rise & $0.2-0.5$ & $60-90$ & $<30$ & $<10$ & $2-4$ & $4-5$ & $0.15-0.35$ \\
\hline LCZ 8 Large low-rise & $>0.7$ & $30-50$ & $<20$ & $40-50$ & $3-10$ & 5 & $0.15-0.25$ \\
\hline LCZ 9 Sparsely built & $>0.8$ & $0-20$ & $60-80$ & $<20$ & $3-8$ & $5-6$ & $0.12-0.25$ \\
\hline LCZ 10 Heavy industry & $0.6-0.9$ & $20-30$ & $40-50$ & $20-40$ & $5-15$ & $5-6$ & $0.12-0.20$ \\
\hline LCZ A Dense trees & $<0.4$ & $<10$ & $>90$ & $<10$ & $3-30$ & 8 & $0.10-0.20$ \\
\hline LCZ B Scattered trees & $0.5-0.8$ & $<10$ & $>90$ & $<10$ & $3-15$ & $5-6$ & $0.15-0.25$ \\
\hline LCZ C Bush, scrub & $>0.9$ & $<10$ & $>90$ & $<10$ & $<2$ & $4-5$ & $0.15-0.30$ \\
\hline LCZ D Low plants & $>0.9$ & $<10$ & $>90$ & $<10$ & $<1$ & $3-4$ & $0.15-0.25$ \\
\hline LCZ E Bare rock or paved & $>0.9$ & $<10$ & $<10$ & $>90$ & $<0.25$ & $1-2$ & $0.15-0.30$ \\
\hline LCZ F Bare soil or sand & $>0.9$ & $<10$ & $>90$ & $<10$ & $<0.25$ & $1-2$ & $0.20-0.35$ \\
\hline LCZ G Water & $>0.9$ & $<10$ & $>90$ & $<10$ & $/$ & 1 & $0.02-0.10$ \\
\hline
\end{tabular}

a Ratio of the amount of sky hemisphere visible from ground level to that for an unobstructed hemisphere

$b$ Proportion of ground surface with building cover (\%)

c Ratio of pervious plan area (bare soil, vegetation, water) to total plan area (\%)

- Ratio of impervious plan area (paved, rock) to total plan area (\%)

e Geometric average of building heights (LCZs 1-10) and tree/plant heights (LCZs A-F) (m)

$f$ Davenport et al. (2000) classification of effective terrain roughness (z0) for city and country landscapes

9 Ratio of the amount of solar radiation reflected by a surface to the amount received by it. Varies with surface color, wetness, and roughness
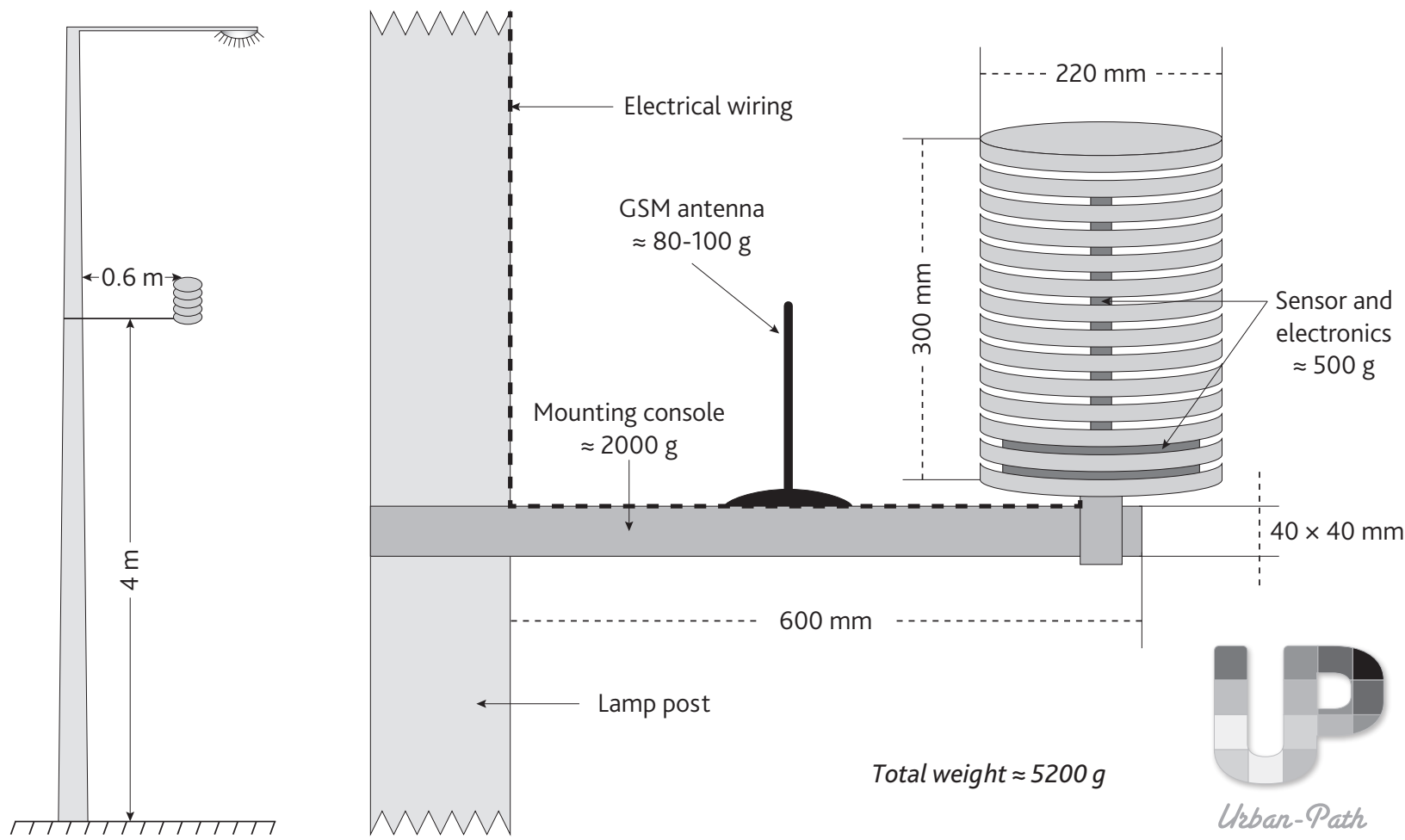

Figure 2. Location and plan of one station of monitoring network system 
Table 4. Classification of urban meteorological stations sites in the city of Novi Sad and its surroundings; u- urban station, $r$-rural station and $m$ - meteorological station of the Republic Hydrometeorological Service of Serbia

\begin{tabular}{|c|c|c|c|c|c|c|}
\hline Station name & $\begin{array}{l}\text { Local climate } \\
\text { zone (LCZ) }\end{array}$ & Latitude & Longitude & Elevation (m) & Station site & Station type \\
\hline ns01 & LCZ 6 & $45^{\circ} 14^{\prime} 1.93^{\prime \prime} \mathrm{N}$ & $19^{\circ} 47^{\prime} 38.73^{\prime \prime E}$ & 77 & Adice & $\mathrm{u}$ \\
\hline ns02 & LCZ 6 & $45^{\circ} 14^{\prime} 7.68^{\prime \prime} \mathrm{N}$ & 1949'15.82"E & 74 & Telep & $\mathrm{u}$ \\
\hline ns03 & LCZ 3 & $45^{\circ} 14^{\prime} 34.32^{\prime \prime} \mathrm{N}$ & $19^{\circ} 48^{\prime} 13.40^{\prime \prime} \mathrm{E}$ & 77 & Telep & $\mathrm{u}$ \\
\hline ns04 & LCZ 5 & $45^{\circ} 15^{\prime} 10.38^{\prime \prime N}$ & $19^{\circ} 47^{\prime} 52.17^{\prime \prime E}$ & 81 & Novo Naselje & u \\
\hline ns05 & LCZ 5 & $45^{\circ} 14^{\prime} 11.74^{\prime \prime} \mathrm{N}$ & $19^{\circ} 50^{\prime} 0.62^{\prime \prime E}$ & 79 & Liman 3-4 & u \\
\hline ns06 & LCZ 5 & $45^{\circ} 14^{\prime} 32.59^{\prime \prime} \mathrm{N}$ & $19^{\circ} 50^{\prime} 50.49^{\prime \prime} \mathrm{E}$ & 79 & Liman 1-2 & $\mathrm{u}$ \\
\hline ns07 & LCZ 2 & $45^{\circ} 14^{\prime} 43.80^{\prime \prime} \mathrm{N}$ & $19^{\circ} 49^{\prime} 56.36^{\prime \prime} \mathrm{E}$ & 79 & Grbavica & $\mathrm{u}$ \\
\hline ns08 & LCZ 2 & $45^{\circ} 15^{\prime} 7.46^{\prime \prime} \mathrm{N}$ & $19^{\circ} 51^{\prime} 1.05^{\prime \prime E}$ & 81 & Center & u \\
\hline ns09 & LCZ 2 & $45^{\circ} 15^{\prime} 18.49^{\prime \prime} \mathrm{N}$ & $19^{\circ} 50^{\prime} 28.60^{\prime \prime} \mathrm{E}$ & 79 & Center & u \\
\hline ns10 & LCZ 3 & $45^{\circ} 15^{\prime} 58.52^{\prime \prime} \mathrm{N}$ & $19^{\circ} 50^{\prime} 25.73^{\prime \prime E}$ & 77 & Podbara & $\mathrm{u}$ \\
\hline ns11 & LCZ 2 & $45^{\circ} 15^{\prime} 50.93^{\prime \prime} \mathrm{N}$ & $19^{\circ} 50^{\prime} 49.61 " \mathrm{E}$ & 79 & Podbara & $\mathrm{u}$ \\
\hline ns12 & LCZ 8 & $45^{\circ} 15^{\prime} 14.70^{\prime \prime} \mathrm{N}$ & $19^{\circ} 49^{\prime} 31.15^{\prime \prime E}$ & 77 & Sajam & u \\
\hline ns13 & LCZ 5 & $45^{\circ} 15^{\prime} 41.21^{\prime \prime} \mathrm{N}$ & $19^{\circ} 49^{\prime} 43.50^{\prime \prime} \mathrm{E}$ & 81 & Banatić & $\mathrm{u}$ \\
\hline ns14 & LCZ 5 & $45^{\circ} 15^{\prime} 47.84^{\prime \prime} \mathrm{N}$ & $19^{\circ} 48^{\prime} 42.45^{\prime \prime} \mathrm{E}$ & 78 & Detelinara & $\mathrm{u}$ \\
\hline ns15 & LCZ 8 & $45^{\circ} 16^{\prime} 26.04^{\prime \prime} \mathrm{N}$ & $19^{\circ} 49^{\prime} 25.44^{\prime \prime} \mathrm{E}$ & 78 & Industrijska zona- jug & u \\
\hline ns16 & LCZ 10 & $45^{\circ} 16^{\prime} 46.45^{\prime \prime} \mathrm{N}$ & $19^{\circ} 52^{\prime} 9.68^{\prime \prime E}$ & 72 & Rafinerija & u \\
\hline ns17 & LCZ 3 & $45^{\circ} 17^{\prime} 15.15^{\prime \prime} \mathrm{N}$ & $19^{\circ} 49^{\prime} 42.52^{\prime \prime E}$ & 77 & Klisa & u \\
\hline ns18 & LCZ 6 & $45^{\circ} 17^{\prime} 1.63^{\prime \prime} \mathrm{N}$ & $19^{\circ} 50^{\prime} 32.04^{\prime \prime} \mathrm{E}$ & 75 & Klisa & u \\
\hline ns19 & LCZ 2 & $45^{\circ} 15^{\prime} 1.48^{\prime \prime} \mathrm{N}$ & $19^{\circ} 50^{\prime} 15.37^{\prime \prime} \mathrm{E}$ & 79 & Center & u \\
\hline ve01 & LCZ 3 & $45^{\circ} 15^{\prime} 11.20^{\prime \prime} \mathrm{N}$ & $19^{\circ} 45^{\prime} 38.44^{\prime \prime} \mathrm{E}$ & 77 & Veternik & u \\
\hline ve02 & LCZ 6 & $45^{\circ} 14^{\prime} 42.88^{\prime \prime} \mathrm{N}$ & $19^{\circ} 46^{\prime} 29.58^{\prime \prime} \mathrm{E}$ & 76 & Veternik & $\mathrm{u}$ \\
\hline fu01 & LCZ 6 & $45^{\circ} 14^{\prime} 29.48^{\prime \prime} \mathrm{N}$ & $19^{\circ} 42^{\prime} 33.74 " \mathrm{E}$ & 79 & Futog & u \\
\hline pe01 & LCZ 3 & $45^{\circ} 15^{\prime} 9.29 " \mathrm{~N}$ & $19^{\circ} 52^{\prime} 34.25^{\prime \prime} \mathrm{E}$ & 76 & Petrovaradin & $\mathrm{u}$ \\
\hline pe02 & LCZ 6 & $45^{\circ} 14^{\prime} 26.17^{\prime \prime} \mathrm{N}$ & $19^{\circ} 52^{\prime} 51.91 " \mathrm{E}$ & 91 & Petrovaradin & u \\
\hline sk01 & LCZ 3 & $45^{\circ} 13^{\prime} 20.76^{\prime \prime} \mathrm{N}$ & $19^{\circ} 50^{\prime} 43.69^{\prime \prime} \mathrm{E}$ & 118 & Sremska Kamenica & $\mathrm{u}$ \\
\hline ru01 & LCZ B & $45^{\circ} 23^{\prime} 1.62^{\prime \prime} \mathrm{N}$ & 1949'55.55"E & 79 & Čenej & r \\
\hline ru02 & LCZ 9 & $45^{\circ} 11^{\prime} 15.33^{\prime \prime} \mathrm{N}$ & $19^{\circ} 56^{\prime} 14.98^{\prime \prime E}$ & 116 & Sremski Karlovci & $r$ \\
\hline rš01 & LCZ D & $45^{\circ} 19^{\prime} 19.02^{\prime \prime} \mathrm{N}$ & 1949'46.19"E & 81 & Rimski Šančevi & $\mathrm{m}$ \\
\hline
\end{tabular}

LCZs belong to "built types", while LCZ B and LCZ D belong to "land cover types".

The largest part of the investigated area belongs to the open low-rise and compact low-rise LCZ types, followed by open mid-rise and compact-mid rise LCZ types. Low-rise LCZ types are present on the periphery of the city (e.g. Adice, Telep, Klisa, etc.) and in commuter settlements (e.g. Veternik, Futog, Petrovaradin and Sremska Kamenica). Mid-rise LCZ types are present on the periphery of the city (e.g. Novo Naselje, Banatić, Detelinara, etc.), near the city core (e.g. Liman 1, Liman 2, Liman, Liman 4, etc.) and in the city core (e.g. Center, Grbavica, Podbara, etc.). Smaller parts of Novi Sad belong to the large low-rise LCZ type (e.g. Industrial area- south and Industrial area- north located in the northern part of the city; Fair buildings) and heavy industry (Oil refinery located in the northern part of the city), while city sur- roundings is characterized by sparsely built, scattered trees and low plants LCZ types. Accordingly, more station sites were defined inside larger LCZ types- six station sites were defined inside LCZ 3 and LCZ 6, each. Five stations sites were defined inside LCZ 2 and LCZ 5, each, while two stations sites were set inside LCZ 8. One station was defined inside LCZ 9, LCZ 10, LCZ B and LCZ D, each. In total, 28 meteorological stations sites make urban meteorological network in the city of Novi Sad and its surroundings (figure 3).

\section{Examples of urban meteorological stations sites}

Open low-rise (LCZ 6) is the most dominant LCZ type in Novi Sad together with LCZ 3 (compact lowrise). LCZ 6 is characterized by open arrangement of low-rise buildings (1-3 stories). There is abundance of pervious land cover around buildings (front yard, backyard, garden, etc.), while impervious land cov- 


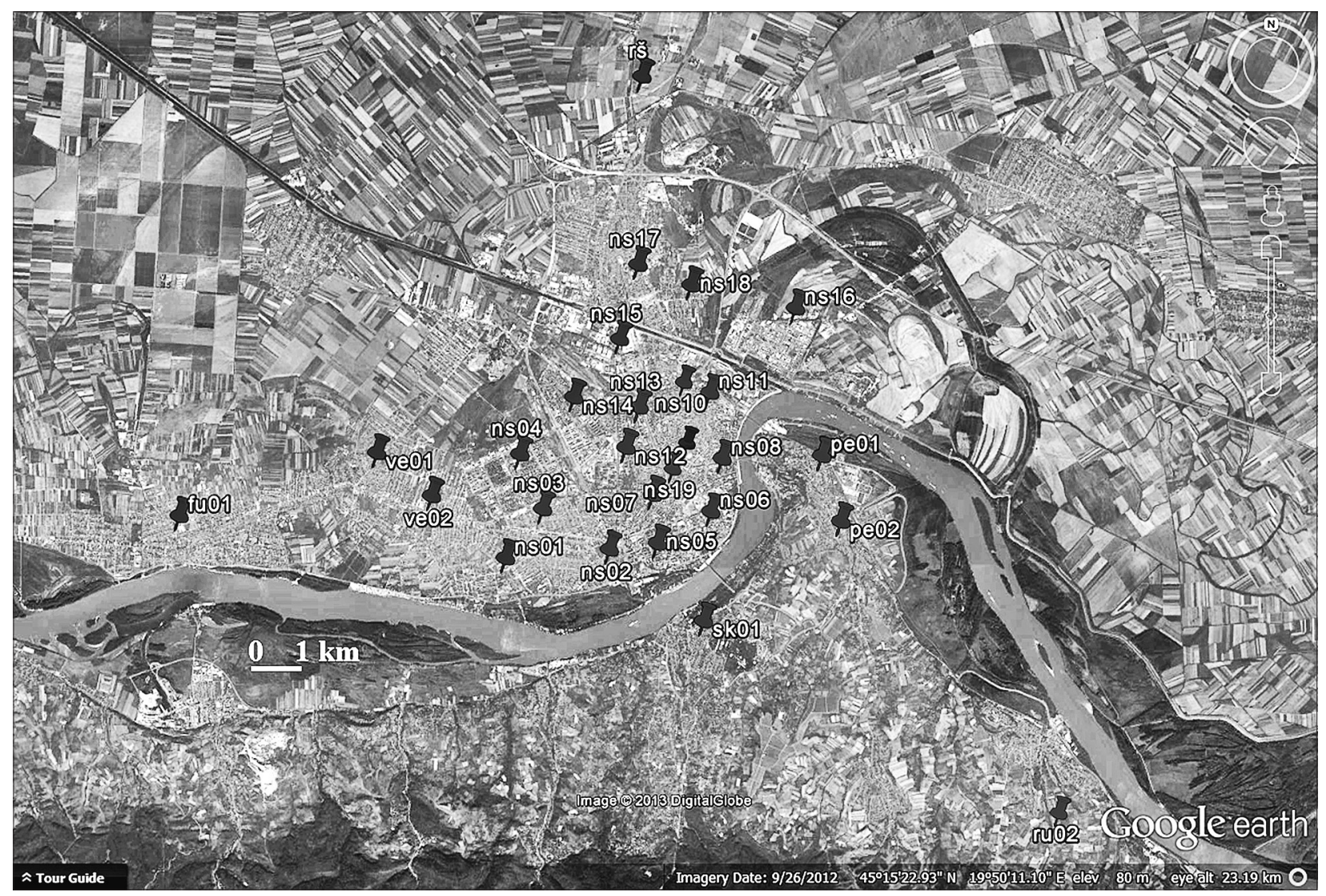

Figure 3. Urban meteorological stations sites in the city of Novi Sad and its surroundings

er is represented by roads and paths made of asphalt and concrete. Brick, wood, tile and concrete are most dominant building construction materials (figure 4).

Compact mid-rise ( $\mathrm{LCZ}_{2}$ ) is the third most domminant LCZ type in Novi Sad together with LCZ 5 (open mid-rise). It is characterized by dense mix of mid-rise buildings (3-9 stories). Land cover is mostly paved, while there are only few trees. Brick, concrete, steel, glass and tile are used as construction materials (figure 5).

Large low-rise (LCZ 8) is present in the northern part of the city in the zone of industrial facilities. It is characterized by open arrangement of large lowrise buildings (1-3 stories) with mostly paved land cov- er between them. Steel, concrete, metal and stone are used as construction materials. Trees are present near the roads and between the buildings (figure 6).

Except stations located in the city (urban stations), two stations sites were chosen outside the city. This was performed for the purpose of inter-urban temperature and relative humidity comparisons, beside the intra-urban ones. Inside LCZ B type (scattered trees) ruo1 station is present (figure 7). This station is located $8.5 \mathrm{~km}$ north from the city outskirts (figure 2). Land cover is mostly pervious with scattered trees and low plants. This station is located at the small sports airport Čenej fields. Inside LCZ 9 type (sparsely built) station ruo2 is present (figure 7). This station is locat-

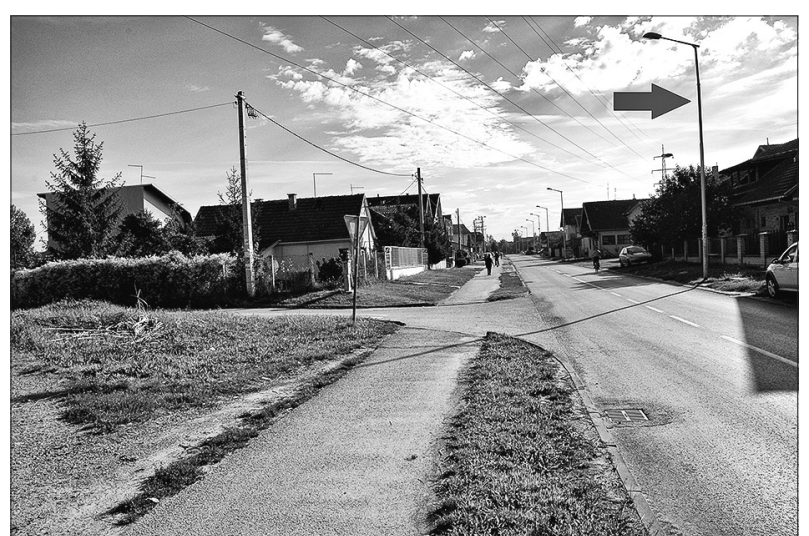

Figure 4. Open low-rise LCZ (LCZ 6) station site in Novi Sad (ns01) 

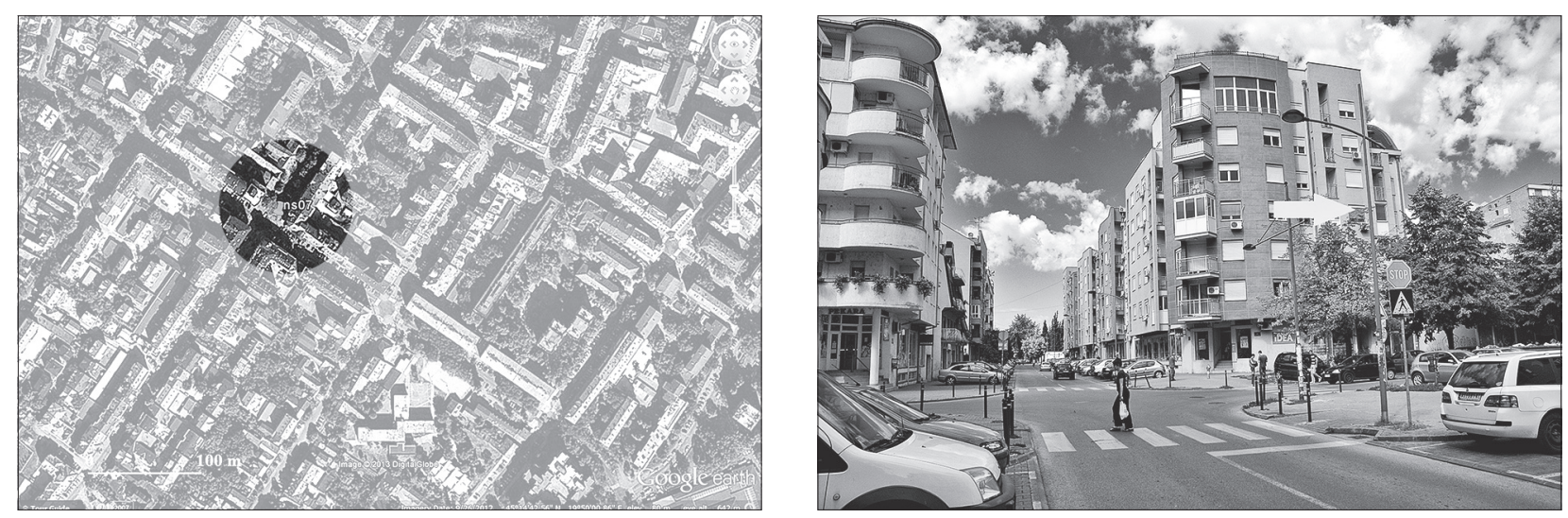

Figure 5. Compact mid-rise LCZ (LCZ 2) station site in Novi Sad (ns07)
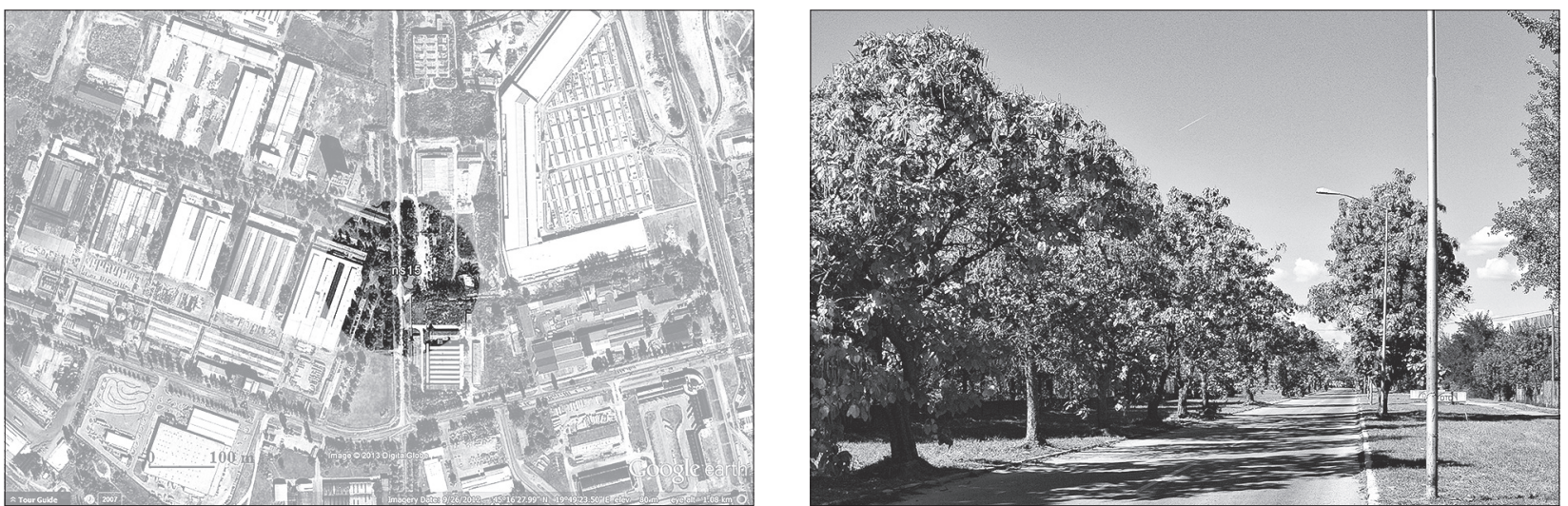

Figure 6. Large low-rise LCZ (LCZ 8) station site in Novi Sad (ns15)
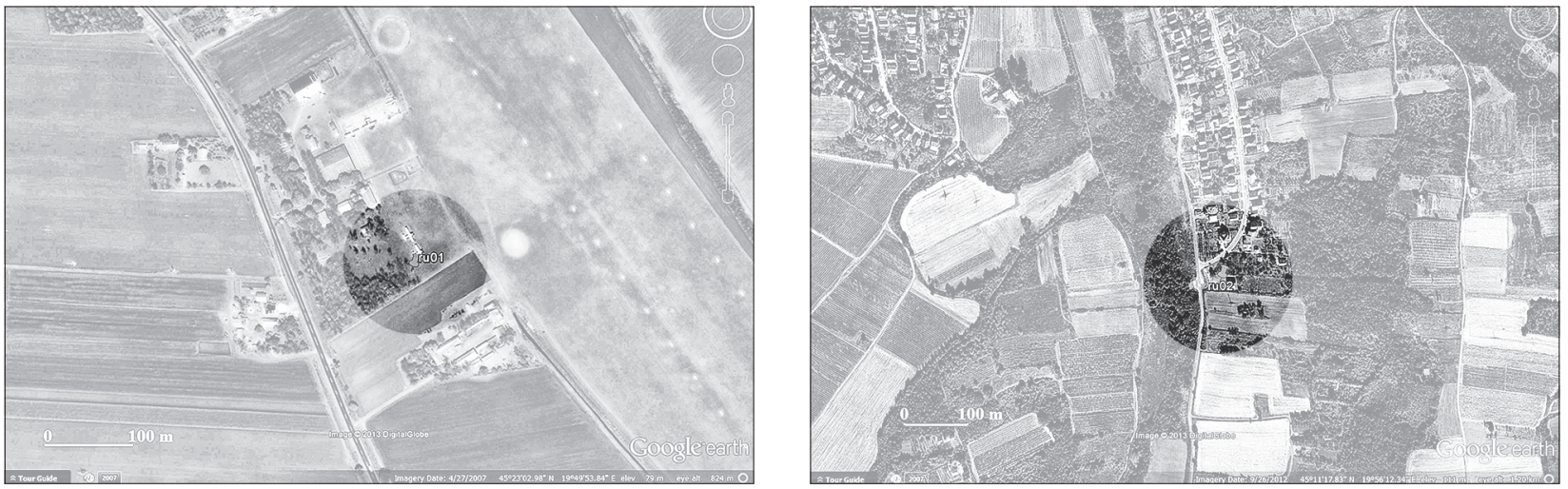

Figure 7. Rural stations ru01 (LCZ D) (left) and ruo2 (LCZ 9) (right) sites near Novi Sad
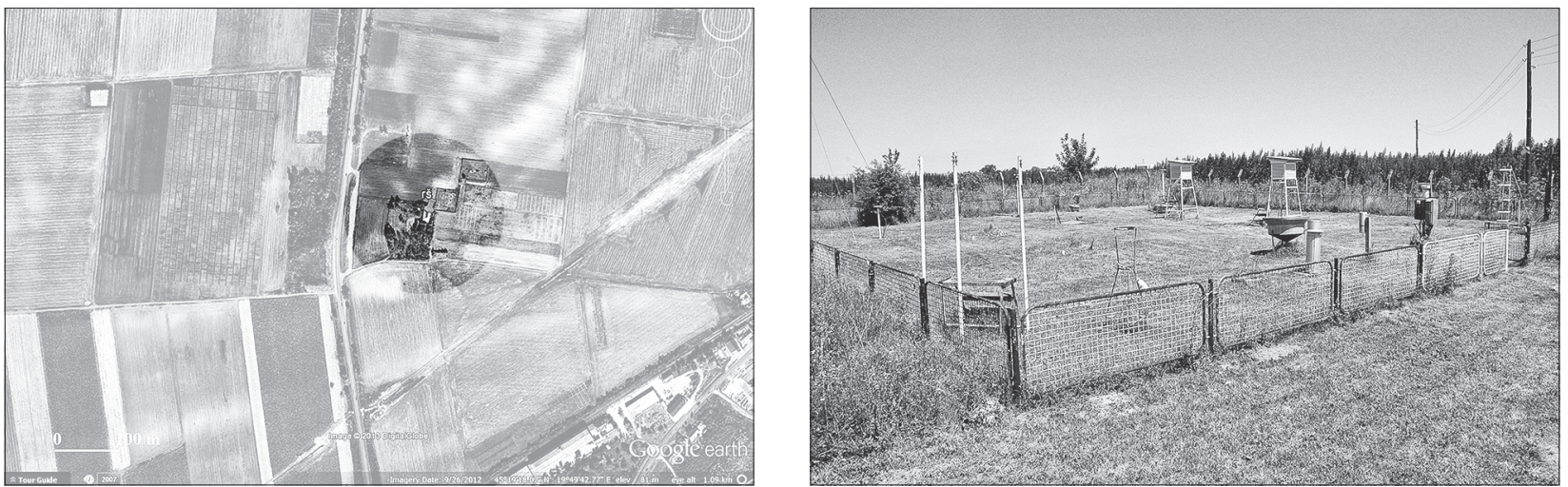

Figure 8. Main meteorological station Rimski Šančevi (ršo1) site near Novi Sad 
ed $6.5 \mathrm{~km}$ southeast from the city outskirts (figure 2) on the southern edge of Sremski Karlovci settlement. It is characterized by sparse arrangement of smallsized buildings in the north and abundance of pervious land cover (low plants and scattered trees).

One station near Novi Sad (Rimski Šančevi) which operates under Serbian Hydrometeorological Service (figure 8) existed before this classification procedure was performed. Data about wind, global radiation, air temperature and relative humidity from this station will be used in the future for the calculation of the thermal PET (Physiological Equivalent Temperature) index for the territory of Novi Sad and its surroundings. This station is located inside LCZ D (low plants) with abundance of pervious land cover with low plants and few trees. It is located $2 \mathrm{~km}$ north from the city outskirts.

Changes to the surface conditions can occur relatively quickly within the urban environment. As such, the collection of regular metadata such as site photographs is needed to further update the classification of urban meteorological sites.

\section{Conclusions}

Urban climate is a phenomenon that is present on a relatively small area but affects many people living in cities. Excess heat present in cities determinates the sensation of (thermal) comfort, health and performance of inhabitants and affects all of their daily or leisure activities. Because of this it is important and necessary to investigate microclimatic conditions in the city. For this purpose urban meteorological stations network has to be established.

Field work, collected stations metadata and Stewart and Oke climate-based classification system from 2012 were used in order to determine local climate zones and 27 potential sites for urban meteorological stations in Novi Sad.

Using all collected data, nine local climate zones were determined on the territory of the city of Novi Sad and its surroundings. Defined LCZ types are as follows: LCZ 2, LCZ 3, LCZ 5, LCZ 6, LCZ 8, LCZ 9, LCZ 10, LCZ B and LCZ D. The largest part of the investigated area belongs to the open low-rise and compact low-rise LCZ types, followed by open mid-rise and compact-mid rise LCZ types. Low-rise LCZ types are present on the periphery of the city and in commuter settlements, while mid-rise LCZ types are present on the periphery of the city, near and inside the city core. Smaller parts of Novi Sad belong to the large low-rise LCZ type and heavy industry, while city surroundings is characterized by sparsely built, scattered trees and low plants LCZ types. More station sites were defined inside larger LCZ types- six station sites were defined inside LCZ 3 and LCZ 6, each. Five stations sites were defined inside $\mathrm{LCZ}_{2}$ and $\mathrm{LCZ}_{5}$, each, while two stations sites were set inside LCZ 8. One station was defined inside LCZ 9, LCZ 10, LCZ B and LCZ D, each. In total, 28 meteorological stations sites will make urban meteorological network in the city of Novi Sad and its surroundings.

In the future, it is planned to use GIS methods developed by Department of Climatology and Landscape Ecology (University of Szeged) for more accurate LCZ mapping of Novi Sad and its surroundings. After this, final urban meteorological station sites will be determined and the deployment of meteorological sensors will occur. This type of monitoring networks developed in Novi Sad and Szeged and the associated continuous data recording, transmission and processing, as well as the real-time public display of the processed data in a spatial (map) form would mean a unique and pioneering innovation development in Central Europe.

\section{Acknowledgements}

This paper is part of the project No. 114-451-2446 funded by the Provincial Secretariat for Science and Technological Development of the Vojvodina Province, Serbia.

\section{References}

Auer, A. H. 1978. Correlation of land use and cover with meteorological anomalies. Journal of Applied Meteorology 17, 636-643.

Balchin, W. G. V. and Pye, M. 1947. A micro-climatological investigation of Bath and the surrounding district. Quarterly Journal of the Royal Meteorological Society, 73, 297- 323.

Chandler, T. J. 1965. The Climate of London. Hutchinson, $292 \mathrm{pp}$.

Davenport, A. G., Grimmond, S. B., Oke, T. R. and Wieringa, J. 2000. Estimating the roughness of cities and sheltered country. Preprints, 12th Conf. on Applied Climatology, Asheville, NC, Amer. Meteor. Soc., 96-99.

Ellefsen, R. 1990/91. Mapping and measuring buildings in the urban canopy boundary layer in ten US cities. Energy and Buildings 15-16, 1025-1049.

Kottek, M., Grieser, J., Beck, C., Rudolf, B., Rubel, F. 2006. World Map of the Koppen-Geiger climate classification updated. Meteorologische Zeitschrift 15, 259-263.

Lazić, L. and Pavić, D. 2003. Climate of Banat. University of Novi Sad, Faculty of Science, Department of Geography, Tourism and Hotel Management, Novi Sad, 171 pp. (in Serbian).

Lazić, L., Savić, S. and Tomić, Ž. 2006. Analysis of the temperature characteristics and trends in Novi Sad 
area (Vojvodina, Serbia). Geographica Pannonica 10, 14-21.

Loridan, T., and Grimmond, C. S. B. 2011. Characterization of energy flux partitioning in urban environments: Links with surface seasonal properties. Journal of Applied Meteorology and Climatology 51, 219-241.

Oke, T. R. 1987. Boundary Layer Climates. 2nd ed. Routledge, $435 \mathrm{pp}$.

Oke, T. R. 2004. Initial guidance to obtain representative meteorological observations at urban sites. IOM Rep. 81, WMO/TD-No. 1250, 47 pp.

Oke, T. R. 2008. Urban observations. Guide to meteorological instruments and methods of observation, Part II of Observing Systems, 7th ed., WMONo. 8, II-11-1-II-11-25.

Popov, Z. and Savić, S. 2010. The urban climate of Novi Sad. The Second Congress of Geographers of Serbia, Serbian Geographical Society- Department of Geography, Tourism and Hotel Management, December 10-11, Novi Sad, Book of abstracts, $62 \mathrm{pp}$. (in Serbian).

Savić, S., Mitrović, M. and Lazić, L. 2012. Urban Heat Island Analysis of Novi Sad. Bulletin of the De- partment of Geography, Tourism and Hotel Management 41, 18-28 (in Serbian).

Stewart, I. D. and Oke, T. R. 2012. Local Climate Zones for Urban Temperature Studies. Bulletin of the American Meteorological Society 93, 1879-1900.

Unger, J., Savić, S., Gál, T. 2011a. Modelling of the Annual Mean Urban Heat Island Pattern for Planning of Representative Urban Climate Station Network. Advances in Meteorology, vol. 2011, Article ID 398613, 9 pages. doi:10.1155/2011/398613

Unger J., Savić, S. and Gal, T. 2011b. Method for representative siting of urban climate station networkNovi Sad (Serbia) as an example. Climate and Constructions- International Conference, October 24-25, 2011, Karlsruhe, Germany, 351-358.

Unger, J., Lelovics, E. and Gál, T. 2013. A vector-based GIS method for mapping of Local Climate Zones and its application in a Central-European city. International conference "Two hundred years of urban meteorology in the heart of Florence: International conference on urban climate and history of Meteorology", Florence, February 25-26.

United Nations (UN) 2012. World Urbanization Prospects. The 2011 Revision. Highlights. 